\title{
Pelatihan Pemantapan Langkah-Langkah Penyelamatan Diri dari Bencana Gempabumi di SDIT Anak Sholeh Mataram
}

\author{
Syahrial Ayub ${ }^{1 *}$, Wahyudi $^{1}$, Muhammad Taufik ${ }^{1}$, Sutrio $^{1}$, Ni Nyoman Sri Putu Verawati ${ }^{1}$

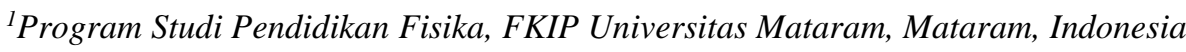

*Corresponding Author: Syahrial Ayub, FKIP

Universitas Mataram, Mataram, Indonesia;

Email:

syahrial ayub@unram.ac.id

\begin{abstract}
Abstrak: Beberapa tahun terakhir ini terjadi banyak peristiwa gempa bumi yang terjadi di wilayah Indonesia. Gempa bumi merupakan peristiwa alam yang belum dapat diprediksi terjadinya sehingga dapat menimbulkan kerugian material dan merenggut nyawa manusia. Oleh karena itu gempa bumi harus diinformasikan kepada seluruh lapisan masyarakat dan mereka perlu dibekali berbagai teknik penyelamatan diri yang merupakan bagian dari kesiapsiagaan. Melalui teknik penyelamatan diri yang tepat masyarakat dapat terhindar dari resiko menjadi korban jika tiba-tiba terjadi gempa bumi. Langkah strategis yang dapat dilakukan adalah memberi pelatihan pada lembaga pendidikan terutama komunitas sekolah. Apabila gempa bumi terjadi pada jam belajar di sekolah, maka dibutuhkan suatu tindakan yang tepat untuk melindungi siswa resiko akibat gempa bumi. Terlebih pada siswa yang memiliki kerentanan tinggi, misalnya siswa sekolah dasar. Kegiatan ini merupakan implementasi kurikulum Mitigasi Bencana Alam Gempa Bumi yang dikembangkan oleh proyek DAPS (Disaster Awareness in Primary School). Kegiatan tanggap bencana ini melibatkan 18 orang siswa kelas V dan 2 orang guru SDIT anak sholeh Mataram. Hasil kegiatan menunjukkan bahwa siswa dan guru mengikuti pembelajaran dengan sungguhsungguh, baik dalam bentuk mendengarkan informasi yang diberikan maupun dalam latihan-latihan yang dipraktekkan. Namun demikian, mereka mengalami hambatan dalam memahami teknik penyelamatan diri dari gempa bumi dan pertolongan pertama pada korban bencana gempa bumi. Berdasarkan temuan tersebut, disarankan agar siswa dan guru melatih diri secara kontinu dan berkelanjutan supaya kesadaran akan bencana dan penyelamatan diri dari bencana betul-betul melekat pada diri mereka.
\end{abstract}

Kata kunci: tanggap bencana, mitigasi, gempa bumi, sekolah dasar

\section{Pendahuluan}

Berdasarkan letak geografis, wilayah kepulauan Indonesia di tempat pertemuan 3 lempeng besar dunia, yaitu lempeng India-Australia (bagian Selatan), lempeng Eurasia (bagian Barat dan Utara), dan lempeng Pasifik (bagian Timur), olehkarena itu Indonesia merupakan wilayah yang sangat rawan terjadinya gempa bumi (Anton, 2012). Menurut data rekaman sebaran episentrum gempa bumi dengan magnitudo 5 dari tahun 19002000 dan menurut peta daerah gempa bumi di Indonesia, propinsi NTB berada di wilayah 4 (Antara News, 2010). Wilayah tersebut merupakan wilayah yang rawan terhadap terjadinya gempa bumi. Selain, NTB berada di dekat pertemuan dua lempeng dunia, NTB juga berada di atas jalur gunung berapi yang aktif di dunia. Posisi ini menjadikan Mataram rentan terhadap bencana alam gempa bumi tektonik maupun volkanik (Departemen Energi dan Sumber Daya Mineral, 2010).

Gempa bumi dengan kekuatan 5,4 SR yang terjadi di Mataram tahun 2004 menimbulkan kerusakan harta benda, sarana prasarana, dan bahkan korban manusia yang terluka dan meninggal dunia (Suara Karya, 2010). Bencana alam tersebut telah membuka mata semua elemen masyarakat secara nasional. Semuanya itu terjadi secara tiba-tiba tanpa bisa diprediksi oleh manusia. Dengan mengetahui bahwa gempa bumi belum bisa diduga secara ilmiah, perlu dilakukan usaha mengurangi resiko akibat yang ditimbulkan gempa bumi. Usaha-usaha yang dilakukan untuk mengurangi resiko gempa bumi disebut Mitigasi Bencana Alam Gempa Bumi (Subagia, 2013). 
Pada kegiatan ini, dilakukan pelatihan bagi siswa dan guru SDIT anak sholeh Mataram dengan tujuan meningkatkan pengetahuan dan keterampilan mereka dalam menghadapi ancaman bahaya gempa bumi serta memahami prosedur dan alat pertolongan pertama pada korban. Dalam kegiatan ini, implementasi kurikulum pendidikan mitigasi bencana alam gempa bumi yang diformulasikan dengan pengetahuan dan pengalaman masyarakat NTB, dalam menghadapi kejadian gempa bumi. Pengetahuan dan pengalaman masyarakat NTB yang telah diwariskan secara turun menurun untuk mengurangi resiko kejadian gempa bumi didefenisikan sebagai kearifan lokal masyarakat NTB dalam mitigasi bencana alam gempa bumi.

Ada berbagai bentuk kearifan lokal masyarakat NTB yang relevan dengan kajian gempa bumi yang berhasil diidentifikasi dan diformulasikan dalam kegiatan ini yang dikelompokkan menjadi dua, yaitu pemberitahuan kejadian gempa kepada orang lain dan pemberitahuan keadaan diri sendiri pada saat gempa terjadi. Ketika terjadi gempa masyarakat NTB umumnya berteriak lindur, lindur, lindur yang artinya terjadi gempa (Subagia, 2012). Teriakan tersebut disampaikan ke orang lain yang ada disekitarnya untuk mengingatkan bahwa telah terjadi gempa. Diharapkan setiap orang menyadari telah terjadi gempa segera melakukan tindakan penyelamatan sesuai dengan keadaan setempat. Disamping berteriak, masyarakat juga memukul benda-benda yang mengeluarkan bunyi, umumnya kentongan, untuk mengingatkan bahwa telah terjadi gempa kepada masyarakat lain yang ada dikejauhan atau yang sedang ada di dalam rumah. Untuk memberitahukan keadaan dirinya masyarakat umumnya berteriak supaya didengar oleh orang lain sehingga bisa secepatnya mendapatkan bantuan.

Penggunaan kearifan lokal dalam mitigasi bencana alam telah banyak digunakan oleh masyarakat. Joko martono (2011) menyatakan bahwa memahami budaya lokal didaerah rawan bencana merupakan alternatif yang sangat masuk akal untuk mengurangi resiko bencana. Salah satu kebiasaan masyarakat yang bisa dirujuk adalah kebiasaan masyarakat di pulau Semeulue. Masyarakat di kepulauan Semeuleue terbiasa berteriak smong ketika air laut surut secara tiba-tiba karena hal itu dipahami sebagai pertanda akan terjadi "ombak besar" yang dikenal dengan tsunami. Pada saat terjadi tsunami Aceh tahun 2004, yang menelan ratusan ribu korban nyawa manusia, masyarakat kepulauan Semeulue gampir tidak ada yang menjadi korban karena ketika air laut surut secara tiba-tiba masyarakat berteriak smong diikuti dengan berlari ke daerah yang lebih tinggi (Lilik Kurniawan, 2011).

Untuk memberikan pemahaman dan pelatihan kepada masyarakat khususnya siswa SD tentang gempa bumi, akibatnya dan cara penyelatan diri maka diberikan kegiatan mitigasi bencana alam gempa bumi. Kegiatan ini tertuang dalam tanggap bencana gempa bumi. Dalam pemberian materi tanggap bencana gempa bumi pada siswa SD digunakan kurikulum pendidikan mitigasi bencana alam gempa bumi yang pernah dikembangkan oleh proyek DAPS bekerja sama dengan kementerian pendidikan nasional. Secara garis besar pengembangan kurikulum tersebut berisikan rumusan Standar Kompetensi (SK), kompetensi dasar (KD), Indikator Pencapaian Kompetensi (IPK) yang dapat dijadikan panduan pembelajaran atau pelatihan. Rumusan SK, KD dan IPK adalah sebagai berikut:

Tabel 1. SK, KD, dan IPK Kurikulum Pendidikan Mitigasi Bencana Alam Gempa Bumi

Standar Kompetensi Kompetensi Dasar Indikator Pencapaian Kompetensi

\begin{tabular}{|c|c|c|}
\hline $\begin{array}{l}\text { 1. Memahami hakekat } \\
\text { gempa bumi }\end{array}$ & 1.1 mendeskripsikan hakekat gempa bumi & $\begin{array}{l}\text { - Mendefenisikan gempa bumi } \\
\text { - Menggambarkan peristiwa akibat gempa } \\
\text { bumi } \\
\text { - Menjelaskan peristiwa gempa bumi }\end{array}$ \\
\hline $\begin{array}{l}\text { 2. Memahami akibat } \\
\text { yang ditimbulkan } \\
\text { gempa bumi }\end{array}$ & $\begin{array}{l}2.1 \text { mendeskripsikan akibat yang ditimbulkan } \\
\text { gempa bumi }\end{array}$ & $\begin{array}{l}\text { - Mengidentifikasi akibat gempa bumi } \\
\text { - Mengelompokkan akibat gempa bumi } \\
\text { - Menjelaskan akibat gempa bumi }\end{array}$ \\
\hline
\end{tabular}




\begin{tabular}{|c|c|c|}
\hline $\begin{array}{l}\text { 3. Memahami cara } \\
\text { cara mitigasi } \\
\text { bencana alam } \\
\text { gempa bumi }\end{array}$ & $\begin{array}{l}3.1 \text { mendeskripsikan cara cara penyelamatan } \\
\text { diri pada saat gempa bumi } \\
3.2 \text { mendeskripsikan cara-cara } \\
\text { mengantisipasi bencana alam gempa bumi }\end{array}$ & $\begin{array}{l}\text { - Mengidentifikasi cara penyelamatan diri } \\
\text { ketika terjadi gempa bumi } \\
\text { - Menjelaskan cara-cara penyelamatan } \\
\text { diri ketika gempa bumi } \\
\text { - Melakukan latihan menyelamatkan diri } \\
\text { ketika gempa bumi } \\
\text { - Mengidentifikasi cara-cara } \\
\text { mengantisipasi bencana alam gempa } \\
\text { bumi } \\
\text { - Mengambarkan peta evakuasi } \\
\text { - Membuat model antisipasi } \\
\text { penyelamatan diri pada saat gempa bumi }\end{array}$ \\
\hline
\end{tabular}

Selain dalam bentuk deskripsi SK, KD, dan IPK, kurikulum pendidikan mitigasi bencana alam gempa bumi juga dilengkapi dengan uraian materi pelatihan. Cara pelaksanaan pelatihan terdiri atas materi teoritis berupa pemahaman siswa terhadap hakekat gempa bumi, cara melakukan mitigasi, dan prosedur pertolongan pertama korban gempa bumi, serta materi praktek berupa cara melakukan mitigasi diri dan orang lain.

\section{Metode}

Kegiatan pengabdian ini, menempuh langkah langkah sebagai berikut:

1) Memberikan pembelajaran bagi siswa dan guru SDIT anak sholeh Mataram tentang pengetahuan gempa bumi, mitigasi bila terjadi gempa bumi dan prosedur pertolongan pertama pada korban gempa bumi dalam hal meningkatkan tanggap bencana gempa bumi bagi siswa dan guru SDIT anak sholeh Mataram.

2) Demontrasi dan simulasi tentang mitigasi gempa bumi dan prosedur pertolongan pertama pada korban gempa bumi.

3) Diskusi dan tanya jawab dengan siswa dan guru SDIT anak sholeh Mataram tentang tanggap bencana gempa bumi.

4) Pemutaran video tentang mitigasi gempa bumi dan pertolongan pertama pada korban gempa.

Secara keseluruhan, kegiatan ini dilaksanakan dengan tahapan sebagai berikut: 1) melakukan pembelajaran tentang pengetahuan gempa bumi, mitigasi gempa bumi dan prosedur pertolongan pertama pada korban gempa bumi, 2) Simulasi penyelamatan diri dari gempa bumi bila berada di dalam kelas, dan di luar kelas serta pertolongan pertama bagi korban gempa bumi, 3) Pemutaran video tentang tanggap bencana gempa bumi. Kegiatan ini dilibatkan 18 orang siswa dan 2 orang guru SDIT anak sholeh Mataram selama satu hari dengan perincian kegiatan sebagai berikut.

Pertama, siswa diajak berdiskusi tentang kejadian gempa bumi, dilanjutkan dengan kegitan menggambar peristiwa yang terjadi saat terjadi gempa bumi, dan diakhiri dengan kegiatan menjelaskan gambar yang dibuat di depan kelas. Kedua, siswa diajak berdiskusi tentang akibat dari gempa bumi, dilanjutkan dengan kegiatan menggambar berbagai peristiwa akibat gempa bumi, dan diakhiri dengan kegiatan menjelaskan gambar yang dibuat di depan kelas. Ketiga, siswa diajak untuk berdiskusi tentang cara mengamankan diri ketika terjadi gempa bumi disertai dengan latihan penyelamatan diri dan melakukan pertolongan pertama kepada penderita korban. Keempat, siswa diajak berdiskusi tentang tempat-tempat yang aman untuk melindungi ketika terjadi gempa bumi dan diakhiri dengan membuat peta evaluasi yang dibuat di depan kelas. Terakhir, setelah semua kegiatan selesai, siswa diberikan tes tertulis dalam bentuk isian singkat.

Seluruh kegiatan pelatihan dipandu dengan unit-unit pembelajaran. Ada lima unit pembelajaran yang disiapkan pelatihan mitigasi bencana alam gempa bumi, yaitu: 1) Hakikat Gempa Bumi, 2) Akibat Gempa Bumi, 3) Cara penyelamatan Diri Saat Terjadi Gempa Bumi, 4) Cara Mengantisipasi Gempa Bumi, dan 5) Model Antisipasi Gempa Bumi (Subagia, 2014). Kearifan lokal masyarakat NTB dalam mitigasi bencana alam gempa bumi menjadi bagian isi dari unit-unit 
Tabel 2. Langkah-Langkah Kegiatan

\begin{tabular}{|c|c|c|}
\hline Tahapan & Kegiatan pelatihan & waktu \\
\hline $\begin{array}{l}\text { Kegiatan } \\
\text { awal }\end{array}$ & $\begin{array}{l}\text { Pelatih/guru memberikan apresiasi materi dengan menanyakan kepada peserta } \\
\text { pelatihan berbagai kejadian gempa bumi yang diketahui. }\end{array}$ & 5 menit \\
\hline \multirow[t]{6}{*}{ Kegiatan inti } & $\begin{array}{l}\text { 1. Pelatih/guru memimpin diskusi kelas yang mendiskusikan pengertian gempa } \\
\text { bumi sampai diperoleh simpulan yang diharapkan. }\end{array}$ & 15 menit \\
\hline & $\begin{array}{l}\text { 2. Pelatih/guru membagikan alat-alat menggambar kepada peserta pelatihan dan } \\
\text { meminta setiap peserta untuk menggambarkan kejadian gempa bumi secara } \\
\text { individu }\end{array}$ & 20 menit \\
\hline & $\begin{array}{l}\text { 3. Pelatih/guru meminta siswa membentuk kelompok ( } 3-5 \text { orang ) dan setiap } \\
\text { anggota kelompok diminta untuk menjelaskan gambarnya kepada teman- } \\
\text { temannya. }\end{array}$ & $\begin{array}{l}10-15 \\
\text { menit }\end{array}$ \\
\hline & $\begin{array}{l}\text { 4. Pelatih/guru meminta kelompok untuk memilih gambar terbaik dalam } \\
\text { kelompoknya dan wakil kelompok untuk menjelaskan gambar tersebut didepan } \\
\text { kelas. }\end{array}$ & 5 menit \\
\hline & $\begin{array}{l}\text { 5. Pelatih/guru meminta siswa untuk menempelkan gambarnya di depan kelas dan } \\
\text { meminta semua siswa untuk memilih tiga gambar terbaik dari gambar yang ada. }\end{array}$ & 5 menit \\
\hline & $\begin{array}{l}\text { 6. Pelatih guru menyiapkan apresiasi kepada siswa atas pertisipasinya dan } \\
\text { memberikan penghargaan terhdap semua gambar terpilih yang ditempelkan di } \\
\text { depan kelas sebagai bentuk penilaian. }\end{array}$ & 5 menit \\
\hline $\begin{array}{l}\text { Kegiatan } \\
\text { Akhir }\end{array}$ & $\begin{array}{l}\text { Pelatih/guru menutup pelajaran dengan mengajak semua siswa untuk merangkum } \\
\text { hasil kegiatan belajar yang terdiri atas: pengertian gempa bumi dan kejadian lain } \\
\text { yang disebabkan oleh kejadian gempa bumi sebagai catatan siswa. }\end{array}$ & 10 menit \\
\hline
\end{tabular}

\section{Hasil dan Pembahasan}

Pelaksanaan kegiatan pelatihan tanggap bencana gempa bumi bagi siswa dan guru SDIT anak sholeh Mataram dilaksanakan pada hari Sabtu tanggal 8 Oktober 2016. Berdasarkan pengamatan langsung dan wawancara yang dilakukan terungkap bahwa kegiatan ini sangat bermanfaat karena telah memberikan pengetahuan dan contoh nyata tentang gempa bumi, mitigasi gempa bumi dan prosedur pertolongan pertama bagi korban gempa. Peserta berharap kegiatan ini dapat dilanjutkan secara kontinu dan lebih optimal lagi.

Secara umum, semua siswa yang berjumlah 18 orang dan 2 orang mengikuti pelaksanaan pelatihan secara sungguh-sungguh, baik dalam mendengarkan informasi maupun dalam melakukan praktik-praktik yang diberikan. Materi pendidikan dan pelatihan yang disampaikan ada empat, yaitu hakikat gempa bumi, akibat yang timbulkan, cara penyelamatannya diri saat terjadi gempa bumi, dan cara mengantisipasi kejadian gempa bumi. Informasi disampaikan dengan metode diskusi kelas dan tanya jawab. Praktikpraktik yang dilakukan selama pelatihan terdiri atas pelatihan menggambar berbagai peristiwa yang terkait dengan gempa bumi, ke luar kelas, dan di luar kelas, serta praktik memberikan pertolongan pertama kepada penderita korban gempa.
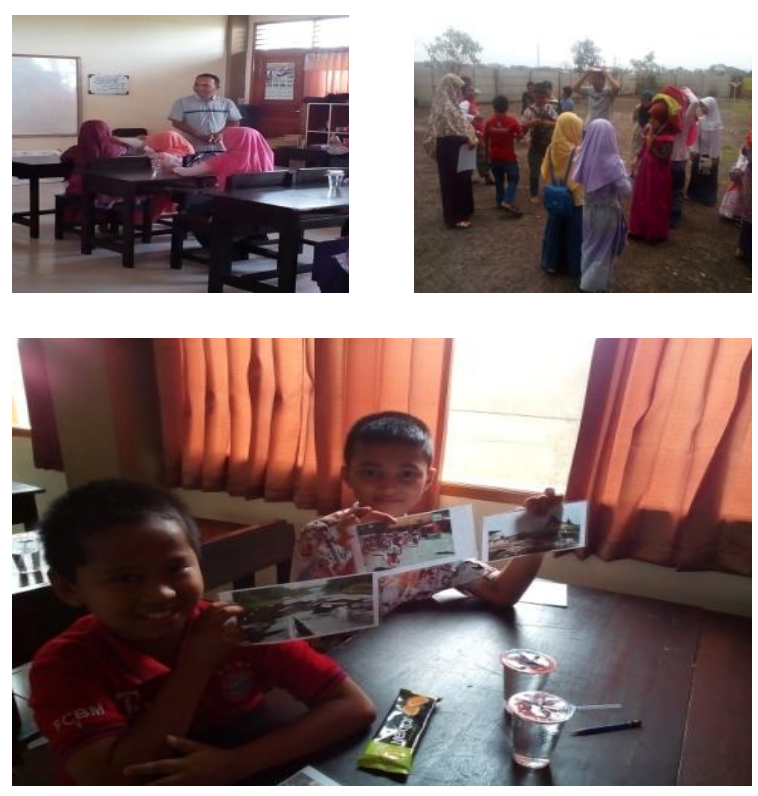

Gambar 1 : Foto-Foto Kegiatan Pengabdian

Di awal kegiatan, siswa terlihat sedikit tegang karena berhadapan dengan orang baru (pelatih) sehingga pelatih perlu beberapa saat untuk melakukan penyesuaian diri. Siswa tidak mau 
menjawab pertanyaan-pertanyaan yang

disampaikan walaupun yang sederhana. Keadaan

tersebut lalu dipecahkan dengan memberikan motivasi berupa hadiah kepada siswa yang mau menjawab pertanyaan yang disamapikan pelatih. Hadiah-hadiah yang diberikan berupa alat-alat pelajaran sederhana, seperti penggaris, penghapus, pensil, dan pulpen yang disampaikan sebagai bahan-bahan pelatihan. Hal tersebut ternyata mampu mencairkan suasana dan siswa mulai mau berprestasi dalam merespon pertanyaan-pertanyaan yang diberikan.

Pada saat kegiatan praktik menggambar peristiwa yang terjadi saat gempa bumi dan cara menyelamatkan diri dari gempa bumi, banyak siswa tidak punya ide yang mesti dibuat. Setelah diberi contoh peristiwa yang terjadi, mereka mulai aktif menggambar sesuai dengan idenya dan mewarnai gambarnya dengan pewarna yang telah disediakan. Namun, tidak semua siswa mampu menuangkan idenya dengan baik dalam bentuk gambar. Beberapa gambar yang dibuat terlihat kurang jelas dan tidak diwarnai secara penuh. Namun demikian, siswa terlihat sangat antusias dalam melakukan kegitan tersebut.

Setelah para siswa selesai menggambar dan membuat langkah-langkah penyelamatan diri dari gempa bumi, mereka diminta untuk membentuk kelompok kecil yang terdiri atas 5-6 orang. Dalam kelompok tersebut mereka diminta untuk menceritakan gambar mereka masing-masing kepada teman-temannya dan memilih gambar terbaik yang akan digunakan sebagai gambar yang mewakili kelompoknya untuk depersentasikan didepan kelas. Kegiatan tersebut semuanya dapat diikuti dengan baik sehingga diperoleh gambar yang dipilih sebagai wakil kelompoknya.

Pada saat presentasi, setiap wakil kelompok diminta untuk menceritakan gambar yang telah dibuat di depan kelas. Lagi-lagi ditemukan bahwa tidak semua siswa yang mewakili kelompoknya mampu mengomunikasikan gambarnya dengan baik. Tampak bahwa siswa mengalami masalah dalam berkomunikasi secara lisan dalam Bahasa Indonesai. Setelah dibantu secara bertahap, akhirnya senua kelompok menyelesaikan tugas presentasinya dengan baik dengan bahasa sederhana.

Selain menggambar, kegiatan praktik yang diberikan dalam pelatihan adalah praktik penyelamatan diri di dalam kelas, ke luar kelas, dan di luar kelas, serta praktik memberikan pertolongan
p-ISSN : 2715-2545

pertama kepada korban dalam bentuk memberika obat merah dan membalut luka. Seluruh kegiatan praktik dapat diikuti dengan baik oleh seluruh siswa. Tampak bahwa sebagian besar siswa sudah memiliki pengetahuan untuk penyelamatan diri ketika terjadi gempa. Hal tersbut dapat dilihat dari kecepatan mereka menerima dan mengikuti petunjuk yang diberikan. Misalnya, ketika mereka dilatih untuk berlindung di bawah meja saat terjadi gempa, dalam waktu singkat mereka bisa melakukannya dengan baik.

Dalam praktik pemberikan pertolongan kepada korban yang dilakukan dalam bentuk pemberian obat merah dan membalut luka, terlihat beberapa siswa masih menujukan keraguan untuk melakukannya. Namun dengan bimbingan pelatih, mereka mampu melakukannya dengan baik.

\section{Kesimpulan}

Kegiatan pengabdian pada masyarakat berupa pelatihan tanggap bencana gempa bumi bagi siswa dan guru SDIT anak sholeh Mataram sangat bermanfaat bagi peserta karena memberikan pengetahuan teoritis dan praktek tentang gempa bumi, mitigasi gempa bumi dan prosedur pertolongan pertama terhadap korban gempa bumi. Hal ini akan meningkatkan kesadaran dan tanggap terhadap bencana alam terutama gempa bumi di sekolah dasar sehingga diharapkan mampu meminimalkan dampak negatif dari gempa bumi.

\section{Saran}

Kegiatan ini sebaiknya lebih sering dilakukan dan melibatkan komunitas sekolah yang lebih banyak, sehingga langkah-langkah yang tepat penyelamatan diri dari bencana gempabumi bila terjadi di sekolah menjadi prilaku yang sudah tertanam pada komunitas sekolah.

\section{Ucapan Terima Kasih}

Terima kasih kami ucapkan kepada kepala sekolah SDIT anak sholeh Mataram beserta bapak/ibu guru disana atas segala bantuan dan partisipasi mereka sehingga kegiatan pengabdian kepada masyarakat ini terlaksana dengan baik dan lancar. Kepada LPPM Universitas Mataram melalui Fakultas Keguruan dan Ilmu Pendidikan yang telah memberikan dana untuk kegiatan ini.

\section{Daftar Pustaka}

Anton, W. 2012 Pakar: Mitigasi Bencana Masuk Kurikulum

Pendidikan. 
http:www.aktual.co/sosial/144525pakar-

mitigasi-bencana-masuk-kurikulum-

pendidikan.

Antara News. 2010. Pendidikan Penanggulangan

Bencana di Sekolah DIY.

http:www.antaranews.com/berita/233563/p

endidikan-penanggulangan-bencana -di-

sekolah-diy.

Departemen Energi dan Sumber Daya Mineral. 2010.Pengenalan Gempabumi Vulcanological Survey of Indonesia (VSI)

Joko Martono 2011. Mitigasi Bencana dalam Perspektif Komunikasi Berkearifan Lokal. Artikel kompasiana http://wwwsosbud.kompasiana.com.

Lilik Kurniawa, Ridawan Yunus, Mohd.Robi Amri, dan Narwawi Pramudiarta. 2011. Indek Rawan Bencana Indonesia. Badan Nasional Penanggulangan Bencana (BNPB).

Joko Martono 2011. Mitigasi Bencana dalam Perspektif Komunikasi Berkearifan Lokal. Artikel kompasiana http://wwwsosbud.kompasiana.com.

Subagia, I Wayan dan I G.L Wiratma. 2013. Mitigasi Becana Alam Gempa Bumi Makalah. Disampaikan dalam Seminar Nasional Research Inovatif (Seminar-1) yang dilaksanakan oleh Lembaga Penelitian UNDIKSHA.

Suara Karya. 2010. Selenggarakan Penanggulangan Bencana di sekolah. http//www.suararyaonline.com/news.htmi? id $=258643$.

Subagia, I Wayan dan I G.L Wiratma. 2013. Mitigasi Becana Alam Gempa Bumi Makalah. Disampaikan dalam Seminar Nasional Research Inovatif (Seminar-1) yang dilaksanakan oleh Lembaga Penelitian UNDIKSHA.

Subagia, I Wayan dan I G.L Wiratma. 2012. Kurikulum Mitagasi Bencana Alam Gempa Bumi Berbasis Kearifan Lokal Masyarakat Bali. Makalah. Disampaikan dalam Seminar Nasional FMIPA UNDIKSHA.

Subagia, I Wayan dan I G.L. Wiratma, dan I Ketut Sudita. 2014. Materi Peltihan Mitigasi Bencana Gempa Bumi Berbasis Kearifan Lokal Masyarakat Bali. Singaraja: Undiksha Press 